\title{
Subsidiary evolution in a transition economy: Kemira GrowHow in the Russian fertilizer market*
}

\author{
Victoria Golikova, Päivi Karhunen, Riitta Kosonen **
}

This paper illustrates subsidiary evolution in a transition economy through the development of a multinational company's Russian subsidiary. Building on the concept of subsidiary evolution, we analyze how knowledge transfer from headquarters and application of the subsidiary management's local knowledge contributed to the process of change. Our empirical analysis is based on four in-depth interviews with senior managers from the company's headquarters and the Russian subsidiary and on documentary evidence. Our results show that the subsidiary capabilities were developed as a combination of knowledge transfer from headquarters at the beginning of the operations and of learning by the Russian management.

Der Artikel illustriert die Entwicklung einer Tochtergesellschaft in einer Transformationswirtschaft am Beispiel der russischen Niederlassung eines multinationalen Konzerns. Aufbauend auf dem Konzept der Filialentwicklung analysieren wir, wie der Wissentransfer von der Muttergesellschaft und die Anwendung der Kenntnisse des lokalen Managements zum Wandlungsprozess beigetragen haben. Unsere empirische Analyse basiert auf vier Tiefeninterviews mit Bereichsleitern aus der Muttergesellschaft und der russischen Tochter sowie auf einer Dokumentenanalyse. Unsere Ergebnisse zeigen, dass die Leistungsfähigkeit der Tochtergesellschaft ausgebaut wurde sowohl durch Wissenstransfer von der Muttergesellschaft zu Beginn des Operationen als auch durch einen Lernprozess auf Seiten des russischen Managements.

Key words: subsidiary evolution, knowledge, foreign entry, Russia

* Manuscript received: 26.01.10, accepted: 05.07.10 (1 revision)

** Victoria Golikova, Dr., Senior Researcher, Institute for Industrial and Market Studies, Higher School of Economics in Moscow, Russia. Main research areas: Institutional changes in transition economies, enterprise restructuring and competitiveness, management practices and productivity and business associations.

Päivi Karhunen, Dr., Head of the research team Russia at the Center for Markets in Transition at Aalto University School of Economics in Helsinki, Finland. Main research areas: Foreign business strategies and the development of entrepreneurship in emerging economies. Corresponding address: paivi.karhunen@ aalto.fi.

Riitta Kosonen, Prof., Director of the Center for Markets in Transition at Aalto University School of Economics in Helsinki, Finland. Main research areas: Strategic adaptation of enterprises and local socio-economic transformation in emerging economies. 


\section{Introduction}

The ways of effectively managing foreign business operations in the Central and Eastern Europe (CEE) have intrigued international business and management scholars since the opening up of the CEE markets. Prior studies have often taken the foreign company's approach and analyzed how global organizational practices can effectively be transferred to the CEE subsidiary or joint venture (Karhunen et al. 2008; Michailova/Sidorova 2010). In contrast, the utilization of local knowledge in the management of operations has received scant attention (Karhunen et al. 2008; Heliste et al. 2008). The acquisition of local resources has been studied almost entirely from the viewpoint of joint ventures, whereas subsidiary management in CEE has been addressed to a considerably lesser extent. We argue first that, in order to succeed in the turbulent business environment of CEE, a foreign company needs not only to transfer its firm-specific advantages to the foreign subsidiary but also to harness local knowledge to implement the firm's strategy. Second, we build on Birkinshaw and Hood (1998) and state that subsidiary capabilities evolve over time as a combination of the headquarters' and local subsidiary management's knowledge. Hence, the subsidiary can increasingly take on a role not only as knowledge receiver but also as a transmitter of knowledge to headquarters.

This paper addresses the question of subsidiary evolution in a transition economy from two complementary viewpoints. First, we investigate how the subsidiary's capabilities have developed over time as a combination of the multinational company's (MNC) global competences together with local knowledge of the subsidiary management. Second, we demonstrate how the capabilities needed in the subsidiary vary over time as a result of changes in its charter (i.e., functions performed). Empirically, we focus on a case representing a Finnish MNC, Kemira GrowHow, which has been selling its products to the Russian market since the Soviet era and which established its subsidiary in Russia in the mid-1990s.

\section{Theoretical background: subsidiary evolution and knowledge integration}

The paper builds on literature addressing two interrelated aspects of subsidiary management: the challenge of global integration versus local responsiveness, and subsidiary evolution. The latter is illustrated through changes in the subsidiary's role and charter over time and is closely linked to the subsidiary's capabilities. Based on this literature, we construct a conceptual model, which we apply to structure our empirical analysis. 


\section{The challenge of global integration versus local responsiveness}

MNCs operating in diverse institutional environments face the challenge of how to balance global integration and local responsiveness (Hurt 2007). In comparison to local firms, MNCs suffer a 'liability of foreignness' due to their limited knowledge of the local market and business practices (Zaheer 1995). To offset this liability, MNCs need to identify and close critical knowledge gaps, that is to say, the gap between the knowledge that it possesses and the knowledge needed to operate in the market (Petersen et al. 2008). Such gaps are particularly great when a MNC from a developed market economy is investing in a transition economy (Lawrence et al. 2005).

Local knowledge comprises information about the local institutions, local demands and tastes and access to local resources and business networks (Makino/Delios 1996). Some forms of local knowledge are specific to local firms, whereas others may be acquired by hiring local managers (ibid). On the other hand, MNCs possess firm-specific advantages, such as a superior technology (Zaheer 1995), or superior organizational or managerial capabilities (Buckley/Casson 1976). To effectively respond to the dual pressure of global integration versus local responsiveness, MNCs need to combine the subsidiary's firm-specific advantages with the local knowledge base.

The need to balance between and integrate both global and local knowledge with MNC strategy is evident in the strategy of dividing specific management functions among them and choosing whether to use global or local knowledge for each function. Studies carried out in the last decade or so, including our own, suggest a rather common division of managerial responsibility in joint ventures and subsidiaries in transition economies: the local management is in charge of the relations with external stakeholders, in particular with those in the public sector, whereas the foreign parent controls the intra-company production process and overall implementation of company strategy, often via appointed expatriate managers in key positions (Karhunen et al. 2008; Child/Yan 1999; Child 2002; Wong et al. 2005). In addition, it has been shown that the subsidiary operations become more integrated within the local operating environment over time (Karhunen 2008), which increases the need for local knowledge.

The question of global integration versus local responsiveness is closely linked to the subsidiary's role in the MNC and to the subsidiary's knowledge base. The concept of subsidiary evolution, which is introduced next, captures this issue.

\section{Subsidiary evolution, charter and capabilities}

Traditional models of MNC assumed that ownership-specific advantages, which are the basis for the competitive advantage of MNCs operating in foreign markets, were developed at corporate headquarters and leveraged overseas through the transfer of technologies to the foreign subsidiaries (Vernon 1966; 
Dunning 1981). Since the 1980s, MNCs have been increasingly perceived as networks of geographically dispersed and differentiated units (Ghoshal/Bartlett 1990). At the same time, it has become apparent that corporate headquarters is not the sole source of competitive advantage for the MNC; subsidiaries have developed their own unique resources and the capabilities to deploy them (Birkinshaw/Hood 1998). Moreover, the subsidiary's role in the MNC network determines the extent to which it receives knowledge from the parent organization and sends it back to headquarters (Gupta/Govindarajan 2000).

The subsidiary's role is originally assigned by headquarters, but it should not be viewed as static. It can change as a result of the actions and decisions taken by the subsidiary management, or as a response to constraints and opportunities in the local market. (Birkinshaw/Hood 1998) There is widespread acknowledgement that subsidiaries evolve over time, typically through the accumulation of resources and through the development of specialized capabilities (Prahalad/Doz 1981; Hedlund 1986). The concept of subsidiary evolution was developed to capture the changes in the role of the subsidiary within the MNC, and the development of subsidiary resources and capabilities (Birkinshaw/Hood 1998).

The subsidiary's role becomes operational through its charter, defined as the business in which the subsidiary participates and for which it is recognized to have responsibility within the MNC (Galunic/Eisenhardt 1996). The charter defines the subsidiary's business activities and the underlying capabilities through which they are implemented. Hence, the charter can be defined in terms of the markets served, the products manufactured, the technologies held and the functional areas covered, or any combination thereof. Similarly, a subsidiary's capabilities to implement its charter can be specific to a functional area, such as production or logistics, or they can be more broadly based. (Birkinshaw/Hood 1998) An example of a broadly based capability which is of particular importance in Russia is government relations (Heliste et al. 2008; Holtbrügge/Puck 2009). Hence, the concept of subsidiary evolution needs to take into account both the charter of the subsidiary and its underlying capabilities.

\section{The conceptual model}

In this paper we examine empirically how the subsidiary charter changes over time, and the implications of this change to capabilities needed within the subsidiary. The development of the capabilities is addressed in terms of a combination of knowledge transferred from headquarters and local knowledge possessed by the subsidiary management. This is illustrated in the following conceptual model. 
Figure 1. Subsidiary evolution through combination of knowledge

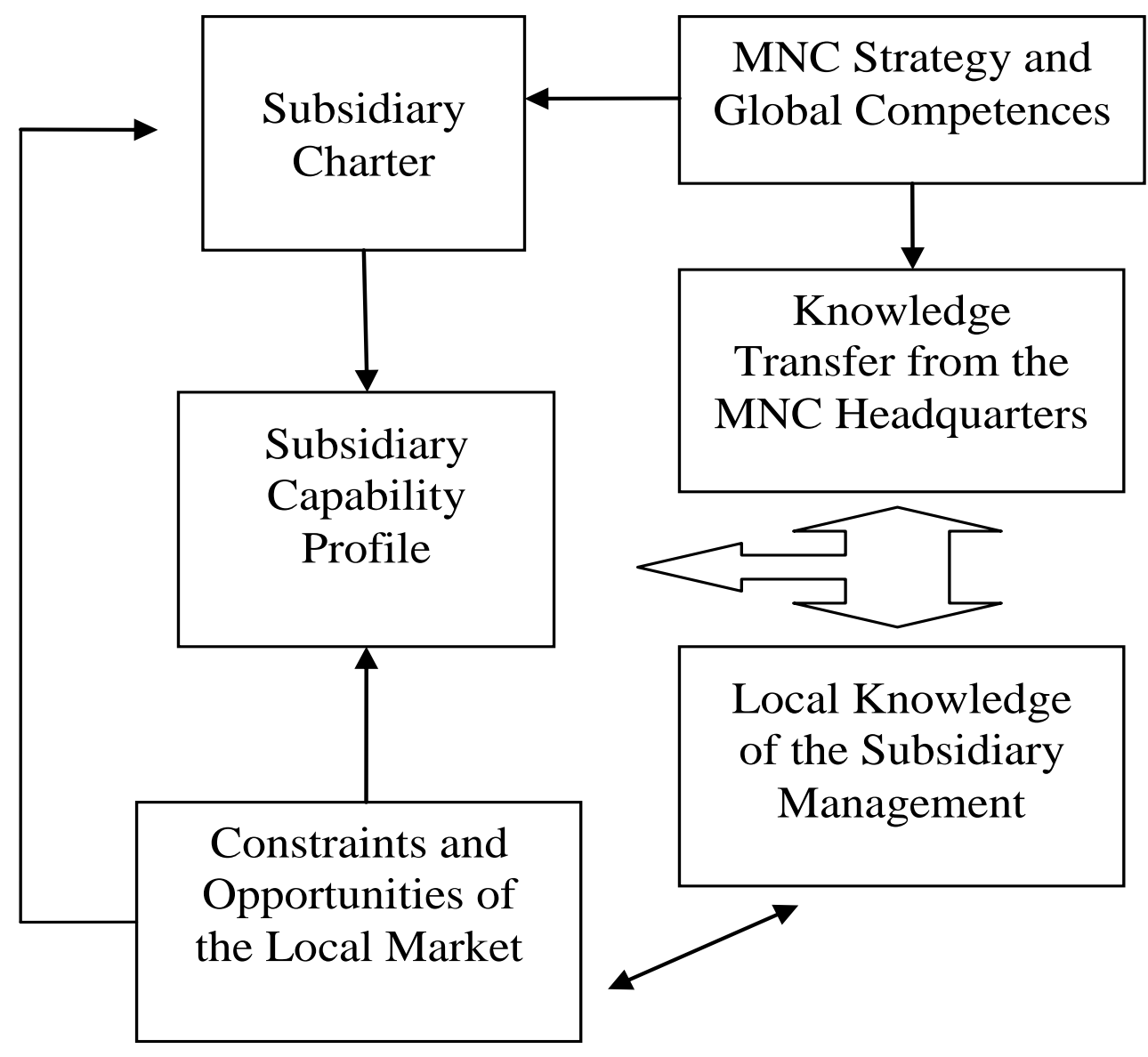

The conceptual model illustrates the dynamic relationship between the subsidiary charter, subsidiary capabilities, the MNC's global strategy and competences, and the local environmental conditions affecting the subsidiary. Our starting point is the subsidiary charter, which, according to Birkinshaw and Hood (1998), is defined as the subsidiary's business activities and the functions that it covers. The subsidiary charter is defined on the one hand by MNC headquarters as part of the MNC's strategy and global competences. On the other hand, the subsidiary charter is determined by the environmental conditions in the subsidiary's host market, as shown by the arrow on the left. In a transition economy such as Russia's, environmental conditions are prone to change and may have a relatively profound effect on the subsidiary's charter.

Furthermore, our model illustrates how the subsidiary's charter largely defines the capabilities needed by the subsidiary in order to implement its activities. In addition, they are dependent on the features of the local environment, that is to say, the constraints and opportunities of the local market. In a transitional environment institutional constraints, such as the personalized nature of business exchange, are of particular importance. Furthermore, the two lower right-hand boxes of our model illustrate the components of capability 
development in the subsidiary. We maintain that the subsidiary's capability profile is formed as a result of transferring the MNC's global competences to the subsidiary from the corporate headquarters and applying local knowledge possessed by the subsidiary management through interaction with the local environment. The three-headed thick arrow in the figure illustrates this knowledge combination. Moreover, we view the subsidiary's capability profile as dynamic, that is, evolving over time as a result of knowledge transfer and learning by the local management. Such a process is investigated in our study through the use of knowledge and the knowledge needs of the subsidiary in different business functions.

In our empirical analysis of the case company's Russian subsidiary, we apply the model in a dynamic manner. We divide our empirical examination into two stages, differing in terms of which functions the subsidiary performs and how the subsidiary's capabilities developed during the operations.

\section{Data and methodology}

This study applied a case-study method, which is particularly useful for analyzing little-investigated phenomena (Eisenhardt 1989; Yin 1994), such as foreign subsidiary evolution in Russia. Our aim was to provide an exploratory analysis of a single case and, thereby, contribute to theory development, rather than looking for explanations that could be generalized to a larger population.

The present study uses multiple sources of evidence, which is characteristic of the case study approach (Eisenhardt 1989; Yin 1994). The main emphasis of the data collection was on qualitative methods, that is to say, interviews supported by documentary evidence. As noted by Yin (1994), one of the most important sources of case-study information is the interview, whereas the most important use of documents is to corroborate and augment evidence from other sources. In this study, interview data was utilized as the main evidence for describing the company-level processes. We ensured the reliability of the interview data by selecting as interviewees key persons with a long history in the company who had an open and cooperative attitude towards the research project. In addition, we retrieved documentary evidence from official company sources to triangulate the interview data and thereby increase the reliability and validity of the study.

Our primary empirical data consists of four in-depth thematic interviews, conducted in two rounds (spring 2008/2009) with the management of the case company in Russia and Finland. The interviewees can be characterized as key informants owing to their senior management positions and long history in the company. The Russian manager had been employed by the case company since the very beginning of the Russian operations. The Finnish interviewee held a senior management position in the company's headquarters, which provided 
him with a good understanding of the company's global strategy in addition to his knowledge about the Russian operations.

We conducted the first round of interviews according to an interview guide (Golikova/Yakovlev 2007). The guide was addressed to top-managers of the companies - 'newcomers' in the regions surveyed (Republic of Karelia and Moscow oblast) - and contained four sets of thematic questions. The first set addressed general information about the company and its position in the Russian market. It was followed by a set of questions addressing the entry strategy of the company into the Russian market and asking the managers to evaluate the business environment in the host country and region, including the means used to overcome any constraints faced by the company. In terms of the company's entry strategy, the questions focused on aspects such as the organization of supply and production, staffing and the potential transfer of technology or know-how to the Russian operations. The third group of questions focused on the current business activity of the company, including the division of managerial responsibilities between the Russian unit's management and headquarters. Finally, the managers discussed the future plans and development perspectives of their respective companies.

The purpose of the second round of interviews was twofold. First, when analyzing the previous interviews, we realized that the answers given to certain questions were important and so we sought additional information. Second, we wanted to have an update of the company's operations due to two major changes which occurred in the company and its operating environment. These changes were the acquisition of Kemira GrowHow by Yara on the one hand, and the global financial crisis on the other.

In addition to interview materials, we used documentary evidence, such as the case company's annual reports and information displayed on its corporate website. This information was used to corroborate information retrieved from the interviews concerning, for example, the timing of different decisions concerning the company's Russian operations. After organizing the data, we merged the interview and documentary evidence into a single narrative, structured according to the interview themes and 'bracketed' into the two time periods.

To 'make sense' of our empirical data (Weick 1979), we followed Langley (1999) and applied a temporal bracketing strategy by separating the case-study data into three successive periods (entry into the Russian market 1996-2001, the development of production operations 2001-2008, and the post-acquisition restructuring 2008-2009) based on certain discontinuities at their frontiers (the 1998 financial crisis and the ownership change and financial crisis in 2008, respectively). The micro-level processes of subsidiary evolution are then studied within each phase, including an examination of how the context affects 
them. Moreover, as a preliminary step for the actual analysis, we applied narrative strategy to organize and describe the data.

\section{Case analysis: Kemira GrowHow in Russia}

In this section we analyze the operations of our case company based on our conceptual model. Prior to that, we provide a brief summary of the operating context: the Russian fertilizer industry, and the case company and its operations in Russia.

Figure 2. Production and domestic demand for mineral fertilizers by the Russian agricultural sector 1990-2009, million tons of primary material

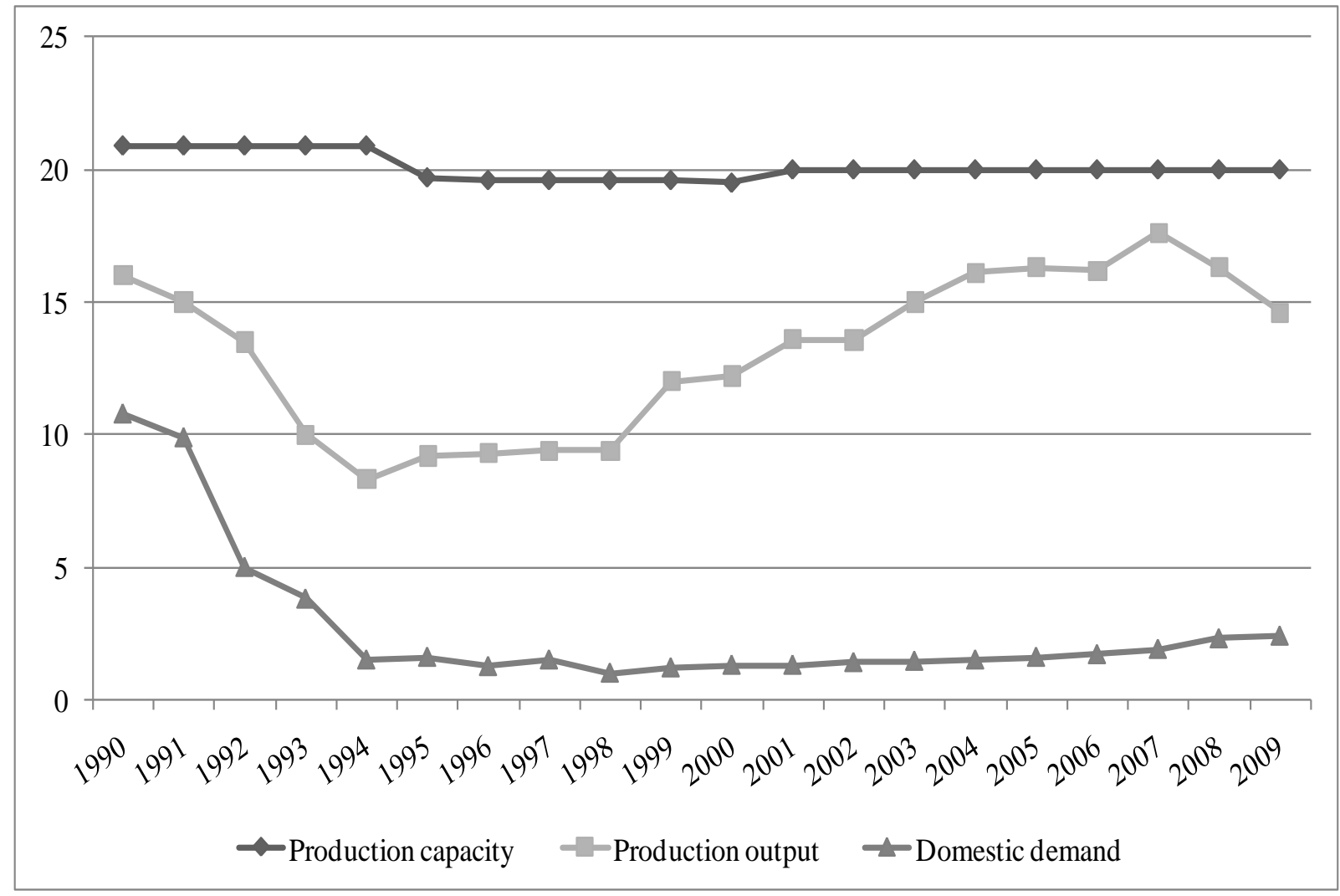

\section{Russian fertilizer market in brief}

Fertilizer production can generally be divided into fertilizers produced from nitrogen, phosphorus and potash, or mixtures of these chemicals. Russia is one of the most notable producers of fertilizers in the world, and the majority of its fertilizer production is exported. According to the statistics of the Food and Agriculture Organization of the United Nations (FAOSTAT), Russia's annual share of exports of total production volume in two of the three main fertilizer categories (phosphate and potash fertilizers) has been close to $90 \%$ since the mid-2000s. In phosphate fertilizers exports registered for Russian fertilizer companies have even exceeded $100 \%$ since 2003 due to production capacities 
abroad. The domestic demand for fertilizers has remained relatively stable since the mid-1990s when measured in terms of agricultural demand (Figure 2). At the same time, there have hardly been any changes in the production capacity of fertilizers. Consequently, the production volumes have been fluctuating mainly as a result of changes in export demand. Unfortunately, data for the private gardening fertilizer market, which represents an important segment of the market for Kemira GrowHow in Russia, was not available for this article.

As shown in Figure 3, the Russian fertilizer industry is very concentrated among large companies, which control the raw material resources. These include the two potash producers Silvinit and Uralkali, the EuroChem group controlling a number of the country's major nitrogen fertilizer producing factories (such as Nevinnomyssky Azot and Novomoskovskaya Azot), and the Phosagro Group (which controls Ammofos and Apatit).

Figure 3. Annual turnover of largest Russian fertilizer companies in 2007 (RUR $m \ln )$

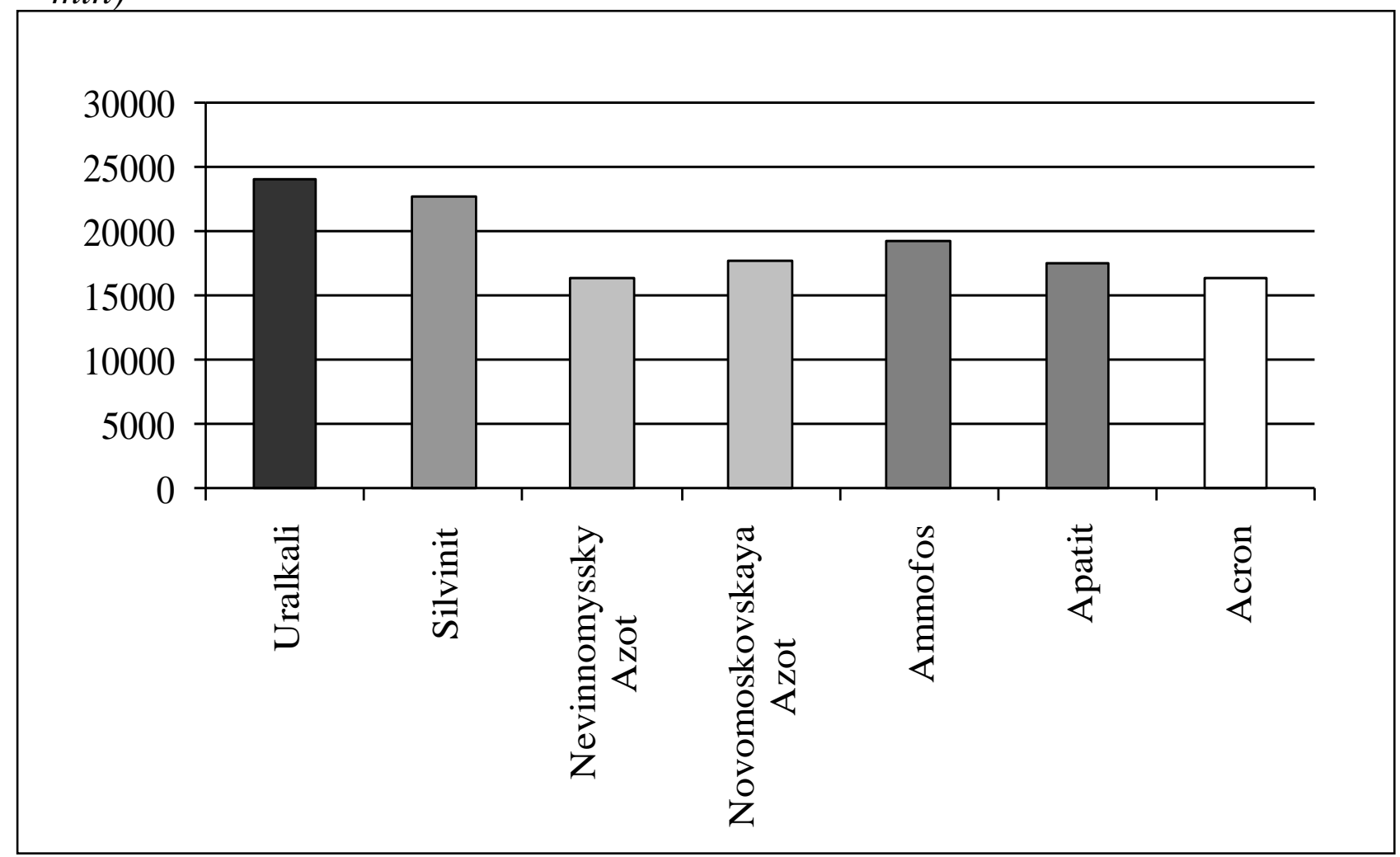

Note: Identical colours indicate part of a group

Source: FIRA PRO database

The share of the six largest producers in total value of the fertilizer production in 2008 was slightly over 90\% (FIRA PRO database). The large players have not yet, however, been particularly interested in the consumer fertilizer segment, which is less concentrated. In addition to importers of Western brands, there are smaller Russian factories that are active in this market. Without revealing exact figures of market share or sales for Russia, Kemira GrowHow identified itself in 
2006 as the best-known fertilizer brand among Russian consumers, and announced having a significant market position in those segments of the fertilizer business that it operates in (home gardening and open field vegetables) in Russia (Kemira GrowHow Annual Report 2006).

\section{Introduction of Kemira GrowHow and its Russian operations}

At the time of our case study, Kemira GrowHow was one of the leading producers of fertilizers and feed phosphates in Europe, with production facilities in eight countries and about 2,100 employees. Its products were sold in over 100 countries. Kemira GrowHow focused on providing customized fertilizers and related services for crop cultivation and feed phosphates for use in animal feed, as well as for process chemicals for selected industrial segments (Kemira GrowHow Annual Report 2006). Annex 1 summarizes the key figures for Kemira GrowHow in 2006.

The history of Kemira GrowHow originates in the fertilizer business of the Finnish state-owned company Kemira group. The fertilizer business was transformed into an independent company in 1994 and named Kemira Agro Ltd. In 2004 it separated from Kemira, changed its name to Kemira GrowHow and became listed on the Helsinki Stock Exchange. Our case study was initiated in January-February 2008 , when a $100 \%$ share of the company had just been sold to the Norwegian fertilizer company Yara. Consequently, Kemira GrowHow ceased to exist as an independent company and operates now as the Finnish business unit of Yara ${ }^{1}$.

Table 1 summarizes the key milestones in Kemira GrowHow and its Russian operations until the acquisition.

Kemira GrowHow's history on the Russian market dates back to the Soviet era, when the Kemira group was an active actor in the Finnish-Soviet clearing trade. This began with the import of raw materials, such as phosphates, potassium and ammonium from the Soviet Union, and was later extended to include the export of phosphate acid to the Soviet Union until the late 1970s (Pessi 2001). A new opening in Kemira's Soviet-trade relations occurred with the signing of the socalled Druzhba (friendship) agreement with the Soviet ministry for agriculture for three years in 1982. The purpose of the agreement was to demonstrate Finnish cultivation technology in the Moscow region and, thereby, open up markets for Finnish agricultural machinery and cultivation equipment (Tinnilä 2006). Encouraged by this opportunity, Kemira opened its own representative office in Moscow in 1985.

1 As our paper is limited in its analysis of the operations prior to the acquisition, we use the name Kemira GrowHow throughout the paper to make the case simpler to follow. 
Table 1. Milestones of Kemira GrowHow and its history in Russia

\begin{tabular}{|c|c|}
\hline Milestone & Year \\
\hline Druzhba agreement between Kemira group and the Soviet ministry for agriculture & 1982 \\
\hline Opening of Kemira group's representative office in Moscow & 1985 \\
\hline Establishment of Kemira Agro Ltd in Finland & 1994 \\
\hline $\begin{array}{c}\text { Establishment of ZAO Kemira Agro and packaging operations in Kotelniki, } \\
\text { Russia }\end{array}$ & 1996 \\
\hline Began production and sales of home gardening fertilizers & \\
\hline Establishment of blending plant in Volokolamsk, Russia & 2001 \\
\hline Exit from Kemira group and listing on Helsinki Stock Exchange as Kemira & 2004 \\
\hline Acquisition of blending plant in Vyborg & 2004 \\
\hline Establishment of blending plant in Tatarstan & 2005 \\
\hline Acquisition of Kemira GrowHow by Yara & 2006 \\
\hline Closure of Kemira GrowHow production operations in Russia & 2007 \\
\hline Licensing of Kemira GrowHow brand to a Russian company & $2008-$ \\
Strengthening of Yara's sales network in Russia & 2009 \\
\hline
\end{tabular}

In 1996 Kemira Agro Ltd established a Russian subsidiary, ZAO Kemira Agro, and began packaging operations in the town of Kotelniki in the Moscow region. In 2001 it established production (a blending plant) in the town of Volokolamsk in the same region. In subsequent years it established blending plants in two other locations (Vyborg 2004; Tatarstan 2005). The former plant also began producing water-soluble fertilizers in 2006. In 2008 Kemira GrowHow operated in Russia in three different sectors of the market: consumer business, the greenhouse sector and fertilizers for open-field vegetables. The company's approach was summarized by a Finnish interviewee in the following words: 'Kemira GrowHow's strategy was to expand slowly the business there and really to learn the market and to learn how to do business in, let's say, a secure way.' The reference to doing business in a secure way addressed the collection of receivables, which was perceived by the company as the key problem in the Russian market.

The presence of Kemira GrowHow in the Russian market drastically changed when it was acquired by Yara. It was decided to close the production operations and focus on the development of Yara's sales network. The name Kemira GrowHow, however, continued to live on the Russian market, as the brand was licensed to a Russian company.

In the following pages we illustrate, using our conceptual model, how the company gradually developed its operations in Russia and what changes resulted from the acquisition. 


\section{First stage: Kemira GrowHow establishes sales and packaging subsidiary in Russia in 1996}

As a continuation to the Finnish-Soviet clearing trade, Kemira Agro decided to establish a subsidiary in Russia in 1995. Consequently, ZAO Kemira Agro was founded in 1996. Water-soluble fertilizers for drip irrigation systems used in greenhouses were its first market niche.

Table 2. Subsidiary charter, capabilities and knowledge combinations during first stage of operations

\begin{tabular}{|l|l|c|c|}
\hline \multicolumn{1}{|c|}{$\begin{array}{c}\text { Subsidiary } \\
\text { charter }\end{array}$} & \multicolumn{1}{|c|}{ Key capabilities needed } & $\begin{array}{c}\text { Match of existing } \\
\text { subsidiary } \\
\text { capabilities with } \\
\text { needed capabilities }\end{array}$ & $\begin{array}{c}\text { Need for } \\
\text { knowledge } \\
\text { transfer from } \\
\text { headquarters }\end{array}$ \\
\hline $\begin{array}{l}\text { Relations to } \\
\text { authorities }\end{array}$ & $\begin{array}{l}\text { Transparency* } \\
\text { Personal relations** }\end{array}$ & Moderate \\
\hline $\begin{array}{l}\text { Financial } \\
\text { management }\end{array}$ & $\begin{array}{l}\text { Compliance with MNC } \\
\text { reporting standards* }\end{array}$ & Low \\
\hline $\begin{array}{l}\text { Human resource } \\
\text { management }\end{array}$ & $\begin{array}{l}\text { Communication competence } \\
\text { in English* }\end{array}$ & Low & High \\
\hline $\begin{array}{l}\text { Distribution } \\
\text { Bargaining skills vis-à-vis } \\
\text { distributors** }\end{array}$ & High & How \\
\hline $\begin{array}{l}\text { Marketing and } \\
\text { Sales }\end{array}$ & $\begin{array}{l}\text { Brand marketing skills* } \\
\text { Knowledge of local sales } \\
\text { arguments** }\end{array}$ & Moderate & High \\
\hline
\end{tabular}

*Defined by MNC global strategy and competences

**Defined by constraints and opportunities of the local market

The way in which the company began to build its operations can be called a relationship-based strategy, where learning played a key role: 'The idea was to establish the brand there, establish the prices and understanding of the market and create relations with producers and customers and so on: to learn how to do business there' (FI). The importance of relations was demonstrated in the way the company selected the site for its subsidiary. The premises for ZAO Kemira Agro were leased from the agro-food holding company Belaya Dacha, located in Kotelniki, in the Moscow region. The holding company, which was a former Soviet agro-food combine, had been Kemira's partner and a key customer for many years.

We next illustrate the subsidiary charter, subsidiary capabilities and use of knowledge during this first stage of operations in reference to our conceptual model. Table 2 summarizes the key elements of this examination.

During the first stage of operations, the subsidiary was a sales unit which implemented a limited number of business functions. The products were delivered from Kemira GrowHow units located outside Russia to distributors and customers in the Russian market. The relations to external stakeholders 
were mainly limited to customers and the authorities. In contrast, the company needed to build its internal management processes practically from scratch.

When establishing the company in Russia, the approach by which government relations (i.e., company registration, obtaining permits) were handled demonstrates an efficient combination of MNC global competences with local knowledge. Finnish traditions of doing business in a totally legal fashion were incorporated within local management practices, as the company step by step went through all the procedures: 'When I was engaged with obtaining all the required permits [...] I was asked: "Why bother? Just sit here behind the fence and nobody can touch you (even if you don't have all the required permits, authors' note)." But the Finns had a different approach: "We don't want to have any problems in the future; this is why the project needs to be implemented from the very beginning according to all requirements"' (RU).

Moreover, headquarters had to invest heavily in knowledge transfer to upgrade the skills of local management. This was due to the lack of appropriate skills and management routines inherited from the Soviet era. To integrate the Russian unit within the global organization, including introducing appropriate financial controls, a Finnish expatriate was nominated as the general director of the Russian unit. However, the company intended to transfer the management to local hands as soon as possible. A key challenge was forming a management team capable of communicating in English. The company took the strategy of upgrading the skills of existing staff, which was inherited from the Kemira representation: 'One of the biggest problems was, in the beginning, the lack of language skills, finding people who could speak English. We considered that it is difficult to find professional people with good English skills at a reasonable salary level. Therefore, we decided to start with the people we have and educate them. We organized language courses' (FI).

Furthermore, headquarters transferred sales and marketing knowledge to the Russian subsidiary through training: 'We also needed to train people in the beginning about the products and how to sell them. Training was organized by our own professionals [from HQs] through interpretation. Product knowledge and how to sell - those kinds of issues were missing a lot'(FI). However, local knowledge was used as well when adapting the company's marketing strategy to the local context: 'When we started to operate on the Russian market we needed to ensure customers that our products are effective. Here we had joint projects with research institutes, to show the results of our scientific development. [...]. We showed that we have a famous institute behind us, which shows that it is worth working with us' (RU).

Finally, the distribution of products required a local contribution to corporate knowledge - in other words, going from a 'how things are done in Russia' approach to convincing the local agents of 'how things should be done': 'For many years we struggled with our distributors to keep their added price at such 
a level that the price of the product for the end customer would be reasonable. [...] In the Soviet Union [...] if you got hold of a product, of which there was a deficit, you put it on a sales desk for a double price. Then you waited for a long time for one customer to come, although you could have sold three at the same time [for a lower price] and earned more. This was difficult to explain to them, but now they understand the logic' (RU). Hence, MNC knowledge concerning distribution could not be directly applied without the local management acting as a 'translator' between the company and its distributors.

\section{Second stage: Kemira GrowHow expands into local production in Russia in 2001}

Next, we illustrate how our case-study company's charter changed from that of a sales unit to that of a production unit. To improve its competitiveness in the Russian market, which had been eroded by the 1998 devaluation of the rouble, Kemira GrowHow decided in 1999 to build a blending plant in the Moscow region (Kemira annual report 1999). Table 3 shows the new business functions that were installed in the company and summarizes the key capabilities and knowledge combinations discovered in our empirical analysis. When the company began blending fertilizers it meant that the subsidiary needed to establish new functions, that is to say, it needed to develop procurement and inbound logistics to obtain the fertilizer components to be blended, the blending process itself, and the outbound logistics to deliver the products to distributors and customers.

The expansion into production intensified the company's relations with authorities, including more frequent inspection visits. Here, the subsidiary continued to follow the corporate policy of being transparent and law-obedient. Consequently, the local management needed to bargain with authorities, who often have a hostile attitude: 'They know that I won't give money, just required documentation. They say "no matter which documents you bring, we will anyway write you a fine" (RU).

Moreover, the importance of proper financial management grew as the company moved from advance payments to more flexible terms. In fact, the importance of knowing the customers was perceived as most critical by the Finnish interviewee: 'Many foreign companies are making mistakes in selling to the kinds of customers they don't know - how well they are in financing and so on.' The financial risk was, to a large extent, managed by the local management's personal network of relations with customers: 'We have some old clients which I have known personally for years and we are almost friends. I already know what kind of assets and business they have' (RU). The value of knowing the customer was emphasized when the global financial crisis hit the Russian fertilizer market in 2008: 'I can't say that because of the crisis someone would have gone bankrupt or disappeared, we don't have such customers. Everyone 
with whom we are working is paying, they do it in small instalments but they continue paying' (RU). Regarding new customers, many of whom often are not transparent, a partial solution was found by collaborating with competitors: 'We discussed bad customers; we established a closed Internet site where information on customers with payment arrears is placed. Earlier there was a period when everybody thought "we got cheated; let someone else get cheated as well". That has now changed' (RU). Finally, the company increased direct selling to big farms to distribute its receivables more widely.

Table 3. Subsidiary charter, capabilities and knowledge combinations during second stage of operations

\begin{tabular}{|c|c|c|c|}
\hline Subsidiary charter & Key capabilities needed & $\begin{array}{c}\text { Match of existing } \\
\text { subsidiary capabilities } \\
\text { with needed } \\
\text { capabilities }\end{array}$ & $\begin{array}{c}\text { Need for } \\
\text { knowledge } \\
\text { transfer from } \\
\text { headquarters }\end{array}$ \\
\hline Government relations & $\begin{array}{l}\text { Transparency* } \\
\text { Personal relations** }\end{array}$ & High & Low \\
\hline Financial management & $\begin{array}{l}\text { Compliance with MNC } \\
\text { reporting standards* } \\
\text { Managing financial risk } \\
\text { associated with local } \\
\text { customers** }\end{array}$ & High & Low \\
\hline $\begin{array}{l}\text { Human resource } \\
\text { management }\end{array}$ & $\begin{array}{l}\text { Competitiveness vis-à-vis } \\
\text { other foreign employers** }\end{array}$ & Moderate & Low \\
\hline $\begin{array}{l}\text { Procurement and inbound } \\
\text { logistics }\end{array}$ & $\begin{array}{l}\text { Personal relations with } \\
\text { local suppliers** } \\
\text { Compliance with MNC } \\
\text { tender procedures* }\end{array}$ & High & Moderate \\
\hline Production & $\begin{array}{l}\text { Compliance with MNC } \\
\text { quality requirements* }\end{array}$ & Low & High \\
\hline $\begin{array}{l}\text { Distribution and outbound } \\
\text { logistics }\end{array}$ & $\begin{array}{l}\text { Bargaining skills vis-à vis } \\
\text { local logistics and } \\
\text { distribution companies } * *\end{array}$ & High & Low \\
\hline Marketing and sales & $\begin{array}{l}\text { Brand marketing skills* } \\
\text { Application of the MNC's } \\
\text { superior technology to } \\
\text { marketing*, ** }\end{array}$ & High & High \\
\hline
\end{tabular}

*Defined by MNC global strategy and competences

**Defined by constraints and opportunities of the local market

The production began under the supervision of Finnish experts who offered production know-how. However, the strategy was to let the Russian management 'learn by doing' instead of transferring Western organization 
models as such: 'The first production unit was organized in a difficult, Russian way, which is much more bureaucratic than in Western Europe. We followed very much the local style, we did not try to implement Western styles there because we considered that it would lead to difficulties [...]. So it was really organized very much in the Russian style, and based on the knowledge that the local people had there; we used their knowledge about how to organize the production' (FI).

Such an approach proved fruitful when the company decided to organize another production unit in Volokolamsk, close to Moscow. Very quickly, the local managers realized that outsourcing represented the most effective means of production: 'We started as a typical Russian company by making everything ourselves. We "hoarded" people; we had a production manager and manager of material economy. Then we realized that there is a more modern way of doing things. We work now through contracts, by outsourcing. [...] We rent the premises and have our technology there. All of the raw materials and final products are ours, but the production process is contracted from an outside organization. We just control the production and packaging process' (RU).

The interplay of global and local knowledge in the subsidiary's operations was evident also in procurement and inbound logistics, where imported packaging materials were gradually replaced by local supplies. In the selection of suppliers the subsidiary management followed Kemira GrowHow's global practice of tender procedure. Another criterion for supplier selection was transparency: 'We won't do business with those who want to evade taxes' (RU).

Local knowledge, in particular the personal relations of the Russian management, was emphasized in the subsidiary's relations to raw material suppliers, which were at the same time its competitors. 'This is probably the biggest difference compared to Western Europe. Personal relations also play a role there but it is more that the big companies have the bargaining power. In Russia that does not play that big a role. Some of those Russian companies, although considering us as competitors, were willing to deliver thanks for the personal relations' (FI).

Personal relations and local knowledge were also highlighted in the distribution and outbound logistics function, particularly in relation to the Russian railway transportation monopoly RZD. It, for example, attempted to press the company for extra pay for weekend service but 'We just said that we would then take all the volume during working days and when they realized that we were not going to pay anything extra, it started to roll again'(RU). On the other hand, the local management could make its position clear by referring to the corporate noncorrupt policy according to international standards.

Moreover, the local team contributed to the corporate sales and marketing strategy by monitoring the Russian market and competitive situation. In 
addition, the company's superior technological expertise was applied in marketing - the subsidiary offered its customers complementary services - soil analysis and associated laboratory analysis. However, the subsidiary did not perform any research and development functions. The company was, nevertheless, in technological terms still ahead of its main Russian competitors. Most of Russian producers were still focusing on single-ingredient fertilizers, whilst Kemira GrowHow produced granulated fertilizers consisting of several ingredients. However, some Russian competitors had already cast their eyes on this product sector in recent years: 'They understood that the future is there [...] Agriculture, [farm] owners, agronomists change, needs change, there are new technologies [...] the business approach needs to be changed as well' (RU).

In addition to the technologically superior product, the quality brand and a sufficient market share of approximately $20 \%$ helped in negotiations with the retail chains. For example, the company managed to avoid paying entrance fees to get its products to the shelves of retail chains.

Finally, during the second stage, following the improvement of the management competences of the local staff, more decision-making power was given to the local management. Although the Russian subsidiary continued to have a foreign general director, the executive power was, in practice, transferred to a Russian CEO who made decisions together with the foreign general director residing in the corporate headquarters.

\section{Epilogue: Yara closes Kemira GrowHow production operations in Russia in 2008-2009}

The original aim of our study was to analyze how Kemira GrowHow implemented its gradual expansion strategy to Russia by combining local and global know-how. This strategy was, however, changed radically when Kemira GrowHow was acquired by the Norwegian fertilizer group Yara in autumn 2007. In 2008 it was decided to close the production operations in Russia and begin serving the Russian market through sales organization only. Hence, the Russian CEO faced, in a sense, the same situation as had existed in the mid-1990s when Kemira GrowHow began its expansion into the Russian market: 'We will work directly through dealers and with farms. The job of the salespeople in the Russian office will be to build this system and assist in closing contracts. It's the function of a representative office' (RU).

The decision to shut down production in Russia was motivated both by reasons related to Yara's overall strategy and to changes in the business environment. First, the market segments that the Russian operations were serving were not those that Yara is globally operating in, and second, the global economic crisis that spread to the Russian economy in autumn 2008 caused a dramatic fall in demand and increased the risk of non-payment by customers. Moreover, the volume of Kemira GrowHow's Russian business was not particularly large and 
Yara's global strategy contrasts with Kemira GrowHow's prior approach. Yara's global strategy is to grow via acquisitions rather than the gradual development of operations. In fact, Yara had tried to enter the Russian market through this strategy some years ago. The trial did not prove successful, which may have also affected the decision to close the Russian production units of Kemira GrowHow.

The closure of operations meant that part of the know-how that Kemira GrowHow had accumulated during its 13 years of production in Russia was lost by Yara. However, the key person in the Russian operations, the CEO of the Russian subsidiary, was able to continue with the company. Interestingly, the way in which the Volokolamsk unit's operations were divested represents a new dimension in the transfer of know-how from Kemira GrowHow (Yara) to Russia. It was decided to sell the business (including production equipment and contracts with customers) to a private Russian company. In addition, the Kemira GrowHow brand, as well as the packaging technology and design, were licensed to this company with a two-year agreement. According to the agreement, Yara continues to supply the licensee with raw materials and ingredients for production. This helps the company to keep control over the Kemira GrowHow brand on the Russian market. As a result of this arrangement, some key persons in the operations moved to the payroll of the licensee company as well.

\section{Discussion and conclusions}

The empirical findings of our case analysis can be summarized as follows. First, we showed how the MNCs global competences were combined with local knowledge in the subsidiary management. The key 'imported' competences of the MNC included a strong brand and the global organizational practices regarding, for example, business planning, reporting and marketing. Here, the MNC needed to transfer knowledge to the subsidiary, as the local managers' knowledge and competences inherited from the Soviet era were inadequate. In contrast, there were functions for which the applicability of the MNC's knowledge and global competences was low due to the peculiarities of the Russian business environment. As a result, the company needed to resort to local knowledge. The local competencies, which were highly personalized to the Russian CEO of the subsidiary, included good personal relations with customers and other stakeholders (research institutes and authorities) and strong negotiation skills. These competencies were applied as tools to acquire local raw materials from Russian suppliers (who at the same time are the company's competitors), to negotiate favourable contracts with retail chains, and to cope with inspection authorities and their demands.

Second, we illustrated how the subsidiary's capabilities developed over time, as the subsidiary management gathered experience with the MNC's ways of doing things and managed the subsidiary functions by 'trial and error'. For example, it 
was illustrated how the staffing policy had been streamlined from the Sovietstyle hoarding of labour, which had characterized the start of the operations. In addition, the subsidiary increasingly contributed to the strategic decisionmaking by acting as an information conduit between the Russian market and headquarters.

The theoretical conclusions of the article are the following. The evolution mechanisms observable in the Russian subsidiary of Kemira GrowHow represented a combination of head-office assignment and local environment conditions. At the first stage, the head office made a deliberate choice to allocate the sales activities to the subsidiary as a response to the changing conditions in the local (Russian) operating environment. The end of the bilateral clearing trade between Finland and Russia forced the company to search for new ways to arrange its sales on the Russian market. In the same way, the financial crisis of 1998 and the subsequent devaluation of the rouble eroded the profitability of sales of imported products. As a consequence, the Russian subsidiary was assigned new functions, due to which its charter changed again.

Interestingly, our case analysis reveals that, particularly in the early stage of operations, the capabilities held by the subsidiary (such as the marketing skills of the personnel) did not match with its charter of a sales subsidiary. Hence, headquarters needed to invest in knowledge transfer to build such capabilities. This can be viewed as a classical example of subsidiary evolution through parent-driven investment (Birkinshaw/Hood 1998). On the other hand, the subsidiary and its management had superior local capabilities, including its public sector relations and knowledge of Russian logistics and distribution, which were invaluable for headquarters. Therefore, subsidiary evolution was, in many respects, driven by contextual host country factors, including the dynamism of the local Russian business environment. This dynamism is illustrated in drastic changes in demand conditions after the two economic crises, the one in 1998 and the other in 2008, in the rapid development of distribution channels by the emergence of retail chains with substantial bargaining power vis-á-vis producers, and in the dual role of large Russian fertilizer companies, such as Kemira GrowHow's raw material suppliers and competitors. Finally, the changes in the subsidiary's charter after the acquisition of its mother company illustrate how the capabilities developed in it suddenly became obsolete. A key question is, whether the new owner will be able to benefit from them. 
Kemira GrowHow's Key Figures, 2006

\begin{tabular}{|c|c|}
\hline Net sales, EUR million & $1,166.2$ \\
\hline Export and foreign operations, \% of net sales & 81 \\
\hline Sales in Eastern Europe (excl. Baltic States), \% of net sales & 11 \\
\hline Operating profit, EUR million & 11.1 \\
\hline Operating profit, \% of net sales & 1.0 \\
\hline Gross capital expenditure, EUR million & 66.3 \\
\hline Return on investment, \% & 2.4 \\
\hline Equity ratio & 37.2 \\
\hline Gearing, \% & 59.5 \\
\hline Average number of personnel & 2,589 \\
\hline
\end{tabular}

\section{Acknowledgements}

We warmly thank the representatives of Kemira GrowHow/Yara Finland: Mr. Olavi Määttä, Director, Crop Cultivation and Mr. Valery Kolesnikov, Director, ZAO Kemira Agro, for their invaluable contribution to our study as key informants. This paper was produced as part of a joint research project between the Center for Markets in Transition and the State University Higher School of Economics, Institute for Industrial and Market Studies. We thank the Russian Foundation for Humanities (grant 07-02-93203a/Ф), the Program of academic research of SU-HSE, and the Academy of Finland (grant 118538) for their financial support.

\section{References}

Birkinshaw, J./Hood, N. (1998): Multinational subsidiary evolution: Capability and charter change in foreign-owned subsidiary companies, in: Academy of Management Review, 23, 4, 773-795.

Buckley, P.J./Casson, M.G. (1976): The future of the multinational enterprise. London: MacMillan.

Child, J. (2002): A configurational analysis of international joint ventures, in: Organization Studies, 23, 5, 781-815.

Child, J./Yan, Y. (1999): Investment and control in international joint ventures: The case of China, in: Journal of World Business, 34, 1, 3-15.

Dunning, J.H. (1981): International production and the multinational enterprise. London: Allen \& Unwin.

Eisenhardt, K.M. (1989): Building theories from case study research, in: Academy of Management Review, 14, 4, 532-550.

FIRA PRO database: Russian company information database, maintained by the First Russian Independent Rating Agency. 
Galunic, D.C./Eisenhardt, K.M. (1996): The evolution of intracorporate domains: Divisional charter losses in high-technology, multidivisional corporations, in: Organization Science, 7, 3, 255-282.

Ghoshal, S./Bartlett, C.A. (1990): The multinational corporation as an interorganizational network, in: Academy of Management Review, 15, 4, 603-625.

Golikova, V./Yakovlev, A. (2007): Analiz modelei vzaimodeistviya krupnykh I srednikh rossijskikh predpiyatij s mestnymi I reginalnymi organami vlasti I negosudarstvennymi preprinimatelskimi ob'jedinenijami. WP/2007/06. Moscow: SU-HSE. (in Russian)

Gupta, A.K./Govindarajan, V. (2000): Knowledge flows within multinational corporations, in: Strategic Management Journal, 21, 4, 473-496.

Hedlund, G. (1986): The hypermodern MNC: A heterarchy?, in: Human Resource Management, 25, 9-36.

Heliste, P./Karhunen, P./Kosonen, R. (2008): Managing foreign business operations through institutional change from transition to post-transition: Finnish firms in Russia and Estonia, in: Journal of East-West Business, 14, 1, 65-99.

Holtbrügge, D./Puck, J.F. (2009): Stakeholder networks of foreign investors in Russia: An empirical study among German firms, in: Journal of East European Management Studies, 14,4, 369-394.

Hurt, S. (2007): What local responsiveness really means to multinational corporations, in: The Journal of American Academy of Business, 11, 2, 43-49.

Karhunen, P. (2008): Toward convergence in the St. Petersburg hotel industry through the lens of institutional theory, in: Journal for East European Management Studies, 13, 2, 106-128.

Karhunen, P./Löfgren, J./Kosonen, R. (2008): Revisiting the relationship between ownership and control in international business operations: Lessons from transition economies, in: Journal of International Management, 14, 1, Special Issue: International Business and Institutional Development in Central and Eastern Europe, 78-88.

Kemira Annual Report (1999): Annual report. Retrieved 15 June, 2010, from web.lib.hse.fi/FI/yrityspalvelin/pdf/1999/Ekemira.pdf.

Kemira GrowHow Annual Report (2006): Annual report, Helsinki. Retrieved 15 June, 2010, from hugin.info/135164/R/1113685/202832.pdf.

Langley, A. (1999): Strategies for theorizing from process data, in: Academy of Management Review, 24, 4, 691-710.

Lawrence, P.R./Vlachoutsicos, C.A./Michailova, S. (2005): From West-East knowledge transfer to effective working relationships: Lessons from Commercial Capital S.A., in: Journal of East European Management Studies, 10, 4, 293-313.

Makino, S./Delios, A. (1996): Local knowledge transfer and performance: Implications for alliance formation in Asia, in: Journal of International Business Studies, 27, 5, 905927.

Michailova, S./Sidorova, E. (2010): Knowledge management in transition economies: Selected key issues and possible research avenues, in: Organizations and Markets in Emerging Economics, 1, 1, 42-55. 
Pessi, Y. (2001): Unpublished interview with Yrjö Pessi, the former CEO of Kemira group, 17.05.2001.

Petersen, B./Pedersen, T./Lyles, M.A. (2008): Closing knowledge gaps in foreign markets, in: Journal of International Business Studies, 39, 7, 1097-1113.

Prahalad, C.K./Doz, Y.L. (1981): An approach to strategic control in MNCs. In: Sloan Management Review, 22, Summer, 5-13.

Russian Association of Fertilizer Producers (2010): O situatsii na rossiiskom rynke mineral'nyh udobrenii i obespechenii mineral'nymi udobreniyami sel'hoztovaroproizvoditelei (About the situation on teh Russian fertilizer market and provision of agricultural producers with fertilizers, in Russian). Presentation of the CEO of Russian Association of Agricultural Producers Igor Kaluzhskii in the meeting of the interdepartmental commission of the Russian Ministry for Agriculture, 12-13 February 2010, Nevinnomyssk city, Stavropol region, Russia. Retrieved 15 June, 2010, from www.rapu-fertilizer.ru/Docs/doc2010021503.pdf.

Tinnilä (2006): Presentation by Consul Aulis Tinnilä in the seminar "Maataloustieteen Päivät", Finland, 11 January 2006.

Vernon, R. (1966): International investments and international trade in the product cycle, in: Quarterly Journal of Economics, 80, 190-207.

Weick, K.E. (1979): The social psychology of organizing. Reading, MA: Addison-Wesley.

Wong, M.C.S./Luk, S.T.K./Li, S.C.Y. (2005): Equity ownership and management control in Sino-foreign joint venture hotels, in: The Service Industries Journal, 25, 1, 117-133.

Yin, R. K. (1994): Case study research, 2nd ed. Newbury Park, CA: Sage.

Zaheer, S. (1995): Overcoming the liability of foreignness, in: Academy of Management Journal, 38, 2, 341-363. 